\title{
Meet the Press: How Voters and Politicians Respond to Newspaper Entry and Exit
}

\author{
By Francesco Drago, Tommaso Nannicini, and Francesco Sobbrio*
}

\begin{abstract}
This paper uses an original dataset covering the presence of local news in medium-large Italian cities in the period 1993-2010 to evaluate the effects of newspaper entry and exit on electoral participation, political selection, and government efficiency. Exploiting discrete changes in the number of newspapers, we show that newspaper entry increases turnout in municipal elections, the reelection probability of the incumbent mayor, and the efficiency of the municipal government. We do not find any effect on the selection of politicians. Competition plays a relevant role, as the effects are not limited to the first newspaper entry. (JEL D72, L11, L82)
\end{abstract}

Truth exists. The issue is finding someone willing to dig it up.

- Indro Montanelli (Italian journalist)

The newspaper industry has been facing a serious crisis for at least the last decade. In most countries, the circulation of existing newspapers has shrunk (see Organisation for Economic Co-operation and Development (OECD) 2010). This decline has raised concerns because a well-functioning and independent press is considered a vital element to inform voters and keep politicians accountable. The idea that news media are beneficial, if not essential, for the health of democracies has a long tradition in the theory of liberal democracy and is well summarized by the words of Thomas Jefferson: "If I had to choose between government without newspapers, and newspapers without government, I wouldn't hesitate to choose the latter."

A growing literature has shown that news media have a relevant effect on electoral participation (Strömberg 2004; Gentzkow 2006; Oberholzer-Gee and Waldfogel 2009; Snyder and Strömberg 2010; Gentzkow, Shapiro, and Sinkinson 2011; and

\footnotetext{
* Drago: Department of Economics, University of Naples, Federico II, Via Cintia Monte S. Angelo, 80126, Napoli, Center for Studies in Economics and Finance (CSEF), and Institute for the Study of Labor (IZA) (e-mail: francesco.drago@unina.it); Nannicini: Department of Economics, Bocconi University, Via Roentgen 1, 20136 Milan, Italy, Innocenzo Gasparini Institute for Economic Research (IGIER), and IZA (e-mail: tommaso.nannicini@unibocconi.it); Sobbrio: Department of Economics and Finance, Catholic University of Milan, Largo Gemelli 1, 20123 Milan, Italy (e-mail: francesco.sobbrio@unicatt.it). We are grateful to two anonymous referees for their useful suggestions on how to improve the paper. We would also like to thank Elena Argentesi, Fabrizio Germano, Valentino Larcinese, Stephan Litschig, Maria Petrova, Mauro Sylos Labini, David Strömberg, Ekaterina Zhuravskaya, and seminar participants at ISNIE 2013; the 2012 Scientific Seminar "Communications and Media Markets: Emerging Trends and Policy Issues;" European University Institute; the ninth Workshop on Media Economics, Moscow; the 2011 Petralia Workshop in Applied Economics; Catholic University of Milan; University of Bologna; University of Florence; and Universidad del Rosario, Bogotá for providing insightful comments and discussions at various stages of this project. Maria Chiara Cavalleri, Giovanni Marin, Ilaria Petrarca, and Nicola Pierri provided excellent research assistance. The usual disclaimers apply.

${ }^{\dagger}$ Go to http://dx.doi.org/10.1257/app.6.3.159 to visit the article page for additional materials and author disclosure statement $(\mathrm{s})$ or to comment in the online discussion forum.
} 
Miner 2012). News media also affect other important electoral and public policy outcomes, such as incumbency advantage (Ansolabehere, Snowberg, and Snyder 2006; Prior 2006; Ferraz and Finan 2008; Snyder and Strömberg 2010; Fergusson 2012) and government spending (Besley and Burgess 2002; Strömberg 2004; Snyder and Strömberg 2010; Eisensee and Strömberg 2007). Yet, the whole spectrum of implications of news media on citizens' welfare have not been completely investigated. In particular, evidence on whether news media and news media competition affect the selection of politicians and their performance once elected is scarce in the literature. In fact, not only having detailed data on politicians' characteristics and measures of government performance under politicians' direct control proves to be difficult, but it is also problematic to have a credible empirical design in which to address these issues.

This paper fills this gap by investigating, within the same framework, how the entry and exit of newspapers providing local news affect electoral participation, political selection (i.e., incumbency advantage and the characteristics of elected officials), and government efficiency at the local level. We also explore the role played by the degree of competition (i.e., the total number of newspapers) in the market for local news. We address these research questions in the Italian context by constructing a new dataset covering the presence of local news provided by newspapers for all Italian municipalities above 15,000 inhabitants from 1993 to 2010. These data are matched with electoral outcomes in local elections where citizens directly elect the mayor, observable characteristics of elected mayors (gender, age, education, employment status), and measures of government efficiency at the municipality level (namely, the speed of revenue collection and the speed of payments, which are two commonly used benchmarks in policy analyses of local budget management in Italy).

Italian municipalities represent a suitable environment in which to assess the overall impact of news media since newspapers still remain a uniquely important source of political information at the local level. Moreover, unlike the national news market which is highly concentrated and subject to capture by political interest groups (see Durante and Knight 2012), the market for local news exhibits a wide range of variation in the extent of newspaper competition both across and within municipalities.

The identification strategy exploits discrete changes in the number of newspapers and the precise timing of these events (as in Gentzkow, Shapiro, and Sinkinson 2011). We provide evidence that this strategy is suitable to identify causal effects also in the Italian context. First, we show that the entry of a newspaper in the market for local news generates a large and discontinuous change in readership per capita. Trends in newspaper readership before and after changes in the supply of newspapers are essentially negligible relative to such changes. In other words, the absence of pretrends in newspaper readership suggests that entry and exit are not endogenously driven by preexisting demand for local news. Second, we show the absence of pretrends in all our outcome variables with respect to newspaper entry and exit, suggesting that omitted variables or reverse causality are not expected to contaminate our results. Finally, we provide evidence that controlling for a large set of (city and macro-region-by-year) fixed effects absorbs the variation of factors potentially correlated to our outcomes and to the dynamics of newspaper entry and exit.

From a theoretical point of view, models of electoral participation suggest that a higher level of voters' information leads to an increase in turnout (Matsusaka 
1995; Feddersen and Pesendorfer 1996; Feddersen 2004). Accordingly, empirical studies typically find that more informed individuals are more likely to turnout (Lassen 2005; Green and Gerber 2008; Degan and Merlo 2011; Larcinese 2009). The empirical evidence emerging from our study is consistent with this literature. Our estimates point out that the entry of newspapers in the market for local news has a positive effect on electoral participation in municipal elections, namely, it increases turnout by 0.45 percentage points. This effect translates into an 18.6 percent "persuasion rate" (see DellaVigna and Kaplan 2007). Our results are in line with those found by Gentzkow, Shapiro, and Sinkinson (2011), who estimate an effect of 0.3 percentage points of newspaper entry on turnout in US presidential and congressional elections.

News media may have different effects on the reelection probability of incumbent politicians. On the one hand, an increase in the number of media outlets decreases the probability of media capture (Besley and Prat 2005). Hence, it decreases the electoral advantage of (corrupt) incumbent politicians. On the other hand, an expansion in the supply of news media may make it easier for good (incumbent) politicians to signal their type (Prat and Strömberg 2011). More generally, it increases the incentive to exert effort for politicians facing reelection concerns (Gentzkow, Shapiro, and Sinkinson 2011; Prat and Strömberg 2011).

Our results show that an increase in the supply of local news enhances the reelection probability of incumbent mayors who decide to rerun by 10.76 percentage points (about 14 percent with respect to their average reelection rate), and it improves the efficiency of local government performance - as measured by the speed of revenue collection — by 2.16 percentage points (about 3 percent). By exploiting an additional institutional feature of Italian municipalities, where elected mayors face a two-term limit, we show that the effect of newspapers on government efficiency is larger (i.e., 4.66 percentage points of higher speed of revenue collection, about 7 percent) when mayors are not term-limited and therefore face reelection incentives. Instead, we find no compelling evidence suggesting that newspapers affect the observable characteristics of elected mayors. On the whole, our evidence suggests that electoral incentives represent the main channel linking newspapers and public policy outcomes. We cannot rule out the existence of any effect on the unobservable characteristics of politicians, but incentives seem to be first-order. While newspapers have a substantial impact on the accountability of elected politicians (i.e., on what they do once in office), they do not seem to affect the selection of politicians (i.e., who gets in office). This suggests that news media play an important role in informing voters and keeping elected politicians accountable, that is, in shaping "real" versus "formal" accountability (Besley 2007).

When decomposing the estimated effects by type of newspaper and by the preexisting market structure, two qualifiers about the impact of newspapers on electoral and public policy outcomes emerge. First, newspaper competition matters. Our results show that the effects of newspaper entry on electoral and public policy outcomes are not significantly smaller when other newspapers are already present in the market for local news. In particular, the effects of newspaper entry on the behavior of voters and politicians are not limited to the first one or two outlets entering the market for local news. The second qualifier concerns the type of newspapers 
driving the detected effects. We find that the positive effects of newspaper entry on electoral participation, on the incumbent mayor's performance during her first term, and, ultimately, on her probability of reelection are mainly driven by local rather than national newspapers, by print rather than online editions, and by preexisting rather than new newspapers. ${ }^{1}$

This paper relates to the recent literature studying the effects of news media on political and public policy outcomes (see Prat and Strömberg 2011 for a comprehensive survey). The papers most closely related to ours are Gentzkow, Shapiro, and Sinkinson (2011) and Snyder and Strömberg (2010). With the first we share the type of media analyzed and the empirical strategy. The authors assemble a long (1869-2004) panel of US newspapers to study the effect of newspaper entry and exit on electoral politics. Their analysis shows that newspaper entry has a positive effect on electoral participation. Newspaper competition does not seem to play a role, as the effect is mostly driven by the first newspaper entering the market. With the second paper we share the goal of studying "the chain of media impacts link by link" (Snyder and Strömberg 2010) by investigating the impact of media on a large set of outcomes to assess the overall mechanism driving the results. The authors use a measure of the match, that is, "congruence," between media markets and US congressional districts (i.e., share of newspaper's readership living in a district) to study the effect of media coverage on voters' information and turnout, incumbency advantage, congressmen behavior, and federal spending in any district. They find that a higher degree of congruence increases voter turnout, incumbency advantage, and leads politicians to pursue the interests of their constituency more effectively. In other words, an increase in news media coverage makes politicians more accountable and more active in providing larger transfers to their districts.

Overall, our paper contributes to the existing literature in different respects. First, while previous results are consistent with a model where media provide information to voters, as we mentioned above, the literature does not provide direct evidence on how and whether this information affects the characteristics of elected politicians and how this translates into changes of government activity. Our setup, where newspapers provide information at the municipality level, and thus also on local politicians, allows us to provide more direct evidence on whether news media influence the selection of mayors, the effort they exert once they are in office, and the mechanisms underlying this process. While all the existing literature has analyzed the effect of news media on redistributive outcomes (e.g., allocation of transfers from the central government, as in Snyder and Strömberg 2010), evidence on whether news media improves the overall efficiency of public policies is still scarce. And while the empirical political economy literature on news media has mostly analyzed the effects of improved media coverage on political and public policy outcomes, our paper provides direct empirical evidence on the effects of increased media

\footnotetext{
${ }^{1}$ National newspapers are defined as outlets with national circulation that may have branches providing local news (i.e., local editions). Local newspapers are defined as outlets whose area of circulation is subnational. Print or offline editions refer to the print editions of newspapers, while online editions refer to newspaper websites with local news. Existing newspapers are newspapers already circulating in city $i$ before the opening of a local edition with specific news on that city. New newspapers are newspapers appearing in the city at the same time as their local edition (see Section I for further details).
} 
competition. Finally, differently from Gentzkow, Shapiro, and Sinkinson (2011), our analysis focuses on the role of newspaper competition in the contemporary news media environment.

The paper is structured as follows. Section I describes the data and institutional setting, as well as the economics of newspaper entry and exit. Section II presents our empirical strategy. Section III shows the results on the effect of newspapers on electoral outcomes. Section IV analyzes the impact of newspapers on the observable characteristics of elected politicians. Section V presents the results on local government efficiency and discusses the mechanism behind our results. Section VI decomposes the effects by market structure and by newspaper type. Section VII discusses some validity tests. Section VIII concludes.

\section{Data and Institutional Setting}

\section{A. Data on Newspapers}

The data on Italian newspapers come from a variety of sources. The Italian Authority for Communication (AGCOM) provides an annual report containing the directory of all existing newspapers in the previous year. This report contains the name of each newspaper, the name and location of the firm editing it, and the number of printed copies. Using this directory, we manually coded the presence and location of every Italian newspaper from 1993 to 2010. In order to reconstruct the presence of a local edition in city $i$ of a newspaper headquartered in another city, we used a variety of sources. First, we directly contacted the major local and national newspapers and asked them the starting date of each of their local editions. Then, we analyzed the detailed information contained in Lenzi (2001), who provides information on all local editions, newspapers, editors, and owners up to 2000. We also gathered information from the detailed annual reports "Il Grande Libro della Stampa Italiana" (1993 to 2010) edited by Prima Comunicazione, the leading specialized journal of the Italian media industry. We cross-checked these data with the detailed information provided by Iannace (1989) and Grandinetti (2008). In order to construct the dataset of newspapers' online editions, we used the information contained in the "Grande Libro della Stampa Italiana," and then we used the website archive.org to establish in which year each newspaper local online edition became fully functional, or ceased to provide news.

The number of newspapers is defined at the city level. Specifically, newspaper local editions are typically headquartered in (and provide news on) the capital of a province (capoluogo di provincia). Moreover, for each newspaper and for each year, we were able to identify whether a newspaper provided only news on the capital of the province or it also provided news on other cities in that province. However, it was not possible to gather information for all newspapers so as to identify which specific noncapital cities within a province were covered by the newspaper. Therefore, we applied a straightforward imputation method. Whenever newspaper $k$ was providing local news on province $j$ and local news was not restricted to the capital, we imputed the presence of local news provided by newspaper $k$ in any city $i$ with more than 15,000 inhabitants belonging to province $j$. We chose cities above 15,000 for 
two main reasons. First, Italian municipalities with more than 15,000 use a runoff electoral system to elect the mayor, while municipalities below this threshold use a single-round system. Second, the mean and median population of Italian cities, in 2010, were around 7,500 and 2,500 people, respectively. Therefore, a municipality with more than 15,000 people is a medium-large city for Italian standards. If a newspaper is providing local news on the cities belonging to a given province, it is very likely that such news will involve (at least) any city with more than 15,000 inhabitants. ${ }^{2}$

Similarly to Gentzkow, Shapiro, and Sinkinson (2011), we consider only newspapers that circulate for at least four weekdays every week. Moreover, we excluded foreign newspapers and nonnews (real estate listings, all-sport newspapers, and financial newspapers). We also excluded newspapers owned by political parties, as they typically provide only national news. Moreover, we adopted the classification of the Italian association of press editors (FIEG) to distinguish between "national" and "local" newspapers (i.e., newspapers whose area of circulation is subnational). Finally, we classify as "existing" all newspapers already circulating in city $i$ before the opening of a local edition covering the same city. On the contrary, we define as "new" a newspaper that begins to circulate in city $i$ along with its local edition on that city. We also gathered data on the number of printed copies at the national level for all newspapers in each year from AGCOM. Moreover, for a subset of newspapers, an independent agency (Accertamenti Diffusione Stampa, ADS) provides yearly certified data on circulation at the province level. In particular, around half of the newspapers in our sample, i.e., all national newspapers and around half of the local newspapers, have certified circulation data at the province level. For the remaining fraction of local newspapers in our sample, we constructed a measure of yearly circulation by weighting the yearly national circulation of each newspaper with the ratio of the population of a given province relative to the total population of all provinces where the newspaper provides local news. ${ }^{3}$ Finally, in order to obtain a measure of readership per capita, we assume that each copy is read by two individuals (as in Gentzkow, Shapiro, and Sinkinson 2011).

\section{B. Data on Local Politics and Municipal Governments}

The starting year of our analysis is 1993 and coincides with the adoption of a new electoral system in Italian municipalities. Specifically, since March 1993, mayors are directly elected with plurality rule (single ballot for municipalities with less than 15,000 inhabitants and runoff for the others). Between 1993 and 2000 the legislative term was four years, while after 2000 the term was extended to five years. Mayors are subject to a two-term limit (unless one of the two terms lasted for less than two years). Italian municipalities are in charge of a wide range of services, from water supply to waste management, from municipal police to certain infrastructures, from housing to welfare policies.

\footnotetext{
${ }^{2}$ Results are robust to applying different population cutoffs (available upon request).

${ }^{3}$ All results on the effect of newspaper entry and exit on readership are robust to restricting the analysis to newspapers with certified data on provincial yearly circulation (see Figure A4 in the online Appendix).
} 
The data on the outcomes of municipal elections come from either the electoral office of the Italian Ministry for Internal Affairs or from the electoral archives of Italian regions. The information on the individual characteristics of elected politicians are gathered from the "Registry of Elected Officials" (Anagrafe degli Amministratori) published by the Italian Ministry for Internal Affairs. Specifically, the Registry of Elected Officials provides information about the gender, age, highest educational attainment (self-declared), political affiliation, and previous job (self-declared) of the elected mayor.

In order to assess the performance of the municipal government, we use two efficiency indicators: the speed of revenue collection (i.e., the ratio between collected revenues and the total amount of assessed revenues that the municipality should collect within the budget year) and the speed of payment (i.e., the ratio between the outlays actually paid and the outlays committed in the municipal budget within the year). These indicators are provided by Associazione Nazionale Comuni Italiani (ANCI), the official association of Italian municipalities, which uses them as efficiency benchmarks to evaluate the management of municipal budgets. As a matter of fact, the delays in revenue collection and payments originate from the gap between cash basis accounting and the accruals principle of accounting; that is, some revenues and payments are recorded even if they may not have been actually received or paid in cash. Most importantly, the timing of cash transfers is under the control of the mayor's cabinet and responds to the effectiveness of budget management. We discuss the interpretation of these indicators as measures of government efficiency in Section V.

To control for possible confounding factors at the local level, we also gathered data on the demographic and economic features of each municipality and province. We can control for the number of resident inhabitants for each municipality in each year. We also use two proxies to control for the economic characteristics of each province in each year. First, we use the yearly unemployment rate at the province level. Second, in order to capture yearly variations in economic growth at the local level, we employ the difference between new and ceased firms in each province in any given year. In the online Appendix, we provide further details on the sources of the variables in our dataset.

\section{Sample Selection and Market Definition}

The dataset contains information on electoral outcomes and characteristics of elected officials from 1993 to 2010. Similarly, the newspaper panel covers the period from 1993 to 2010. Instead, the two measures of local government efficiency cover the period from 1993 to 2007. Table 1 summarizes the descriptive statistics of all the relevant variables.

Since the newspaper, electoral, political selection, and efficiency data are all at the city level, our analysis defines the news market to be a city. In this way we obtain a perfect overlap between the news market and the outcomes of interest. In particular, this precise definition of the news market allows us to take into account the underlying heterogeneity of the effects of newspapers across different news markets.

The final dataset covers 664 Italian municipalities between 1993 and 2010. Over this period, we observe 1,021 city-years with net newspapers entry and 80 city-years 
Table 1-Descriptive Statistics of the Outcome Variables

\begin{tabular}{lrrrrc}
\hline \hline & Mean & SD & Min. & Max. & $\begin{array}{c}\text { Number of } \\
\text { city } \times \text { years }\end{array}$ \\
\hline Turnout & 0.79 & 0.06 & 0.55 & 0.99 & 2,711 \\
Rerun for office & 0.45 & 0.50 & 0.00 & 1.00 & 2,129 \\
Reelected & 0.35 & 0.48 & 0.00 & 1.00 & 2,129 \\
Reelected if rerun & 0.78 & 0.42 & 0.00 & 1.00 & 960 \\
Female & 0.07 & 0.25 & 0.00 & 1.00 & 1,837 \\
Age & 48.99 & 8.66 & 19.00 & 81.00 & 1,837 \\
Years of schooling & 15.43 & 2.33 & 5.00 & 17.00 & 1,837 \\
Not employed & 0.06 & 0.25 & 0.00 & 1.00 & 1,837 \\
Speed of collection & 65.66 & 12.81 & 12.05 & 93.40 & 964 \\
Speed of payments & 75.27 & 6.14 & 45.15 & 96.60 & 964 \\
\hline
\end{tabular}

Notes: Means, standard deviations, minimum and maximum values with the corresponding number of city $\times$ years observations are reported for all outcome variables used in the empirical analysis. "Turnout" is measured as a share (over the total of eligible voters); "Age" and "Years of schooling" are measured in years; "Speed of collection" and "Speed of payments" are measured in percentage points; the other variables are dummies.

Table 2-Market Structure Transition MatriX

\begin{tabular}{lccccc}
\hline \hline & \multicolumn{5}{c}{ Newspapers at $t$} \\
\cline { 2 - 6 } Newspapers at $(t-1)$ & 1 & 2 & 3 & 4 & $5+$ \\
\hline 1 & 174 & 173 & 79 & 19 & 2 \\
2 & 37 & 397 & 201 & 139 & 31 \\
3 & 1 & 11 & 194 & 182 & 61 \\
4 & 0 & 1 & 19 & 234 & 84 \\
$5+$ & 0 & 0 & 0 & 4 & 119 \\
\hline
\end{tabular}

Note: The table refers to the total number of newspapers in the market for local news and shows the number of city $\times$ years in the sample that experienced a given transition between consecutive electoral years, i.e., at time $t$ versus time $(t-1)$.

with net newspapers exit (between consecutive electoral years). In other words, on average, each city experiences 1.53 net entries and 0.12 net exits. Table 2 provides more details on the market structure transition matrix.

Entry episodes are not restricted to news markets with just a few competitors, but they take place everywhere (e.g., 172 markets move from 1 to 2 newspapers, 204 from 2 to 3,182 from 3 to 4,84 from 4 to more than 5). Figure 1 shows the distribution of entries and exits over the sample period. ${ }^{4}$

Before discussing how we exploit the above data to identify the treatment effects of interest, we now describe the drivers of newspaper entry and exit in the Italian context. First, in Section ID, we discuss the evolution of the Italian newspaper industry in the sample period. Then, in Section IE, we empirically analyze the determinants of newspaper entry and exit.

\footnotetext{
${ }^{4}$ Overall, considering both electoral and nonelectoral years, there are 1,656 city-years experiencing net newspaper entry and 346 city-years experiencing net newspaper exit.
} 


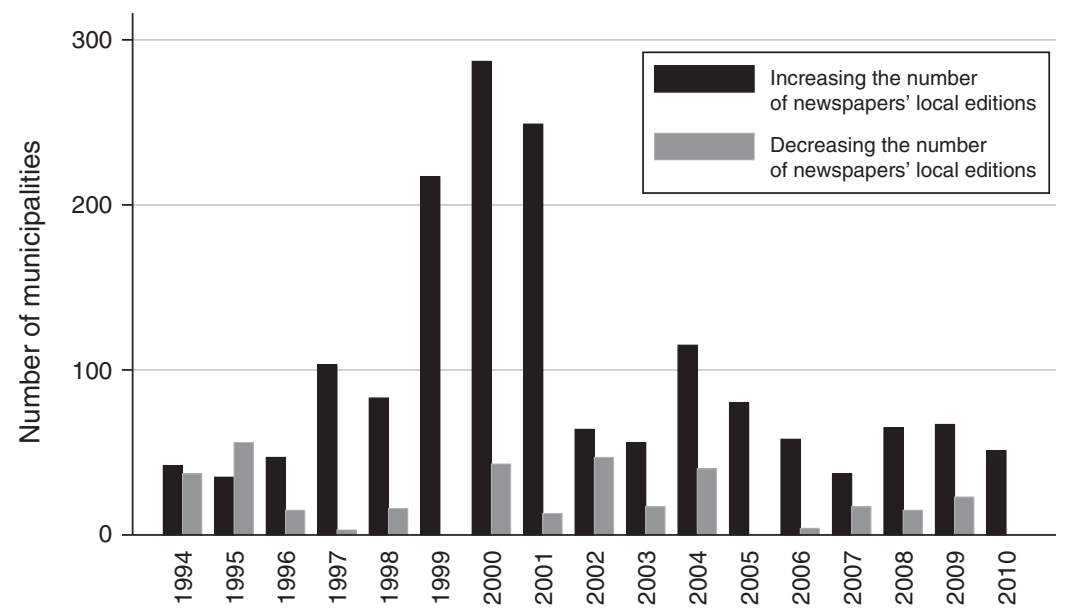

Figure 1. Number of Entries and Exits by Year

Note: Number of municipalities experiencing a net increase or decrease in the number of local news providers in a given year.

\section{Technological Progress and the Expansion of Local News}

Starting from the mid-1980s, the Italian newspaper industry experienced a technological revolution. Newspapers abandoned the expensive linotype and other "hot metal" typesetting machines by gradually adopting phototypesetting equipment and, later on, computerized typesetting and page composition systems (Castronovo 2008; Murialdi and Tranfaglia 2008). These new technologies decreased both the cost and length of production.

These technological innovations have greatly facilitated the expansion of the supply of local news for two main reasons. First, the significant reduction in the fixed cost of production has allowed even small production facilities to be profitable (Grandinetti 2008; Isnenghi 2008). The second reason is represented by the increase in synergies. The introduction of computerized systems in the production process has led to a sharp decrease in the cost of exchanging materials, news agency releases, and advertisements among several connected newspapers. As a result, local and national newspapers have been able to increase their supply of local news at a lower cost (Agostini and Lenzi 2002; Isnenghi 2008)..$^{5}$ Moreover, this expansion in the supply of local news provided by print editions of local and national newspapers has been followed by the creation of newspapers' online local editions.

These technological innovations have allowed the Italian newspaper industry to find a relevant source of profits in the local news market. ${ }^{6}$ The adoption of these

\footnotetext{
${ }^{5}$ Agostini and Lenzi $(2002,434)$ : "Computer networks linked through a fast connection allow the exchange of materials, pages, news agency releases, advertisements among several connected newspapers. The production costs of every newspaper fall [...]. The process frees resources to be allocated to local news."

${ }^{6}$ Fabbri $(2004,89)$ : “In 2000, only 22 TV stations were reaching a revenue of more than 5 billion Italian Liras (i.e., around 2.5 million Euros) with average revenues of 10 billion. In the same year, 37 local newspapers reached 5 billion revenues with average revenues being above 50 billion.” The Italian broadcasting sector is dominated by
} 


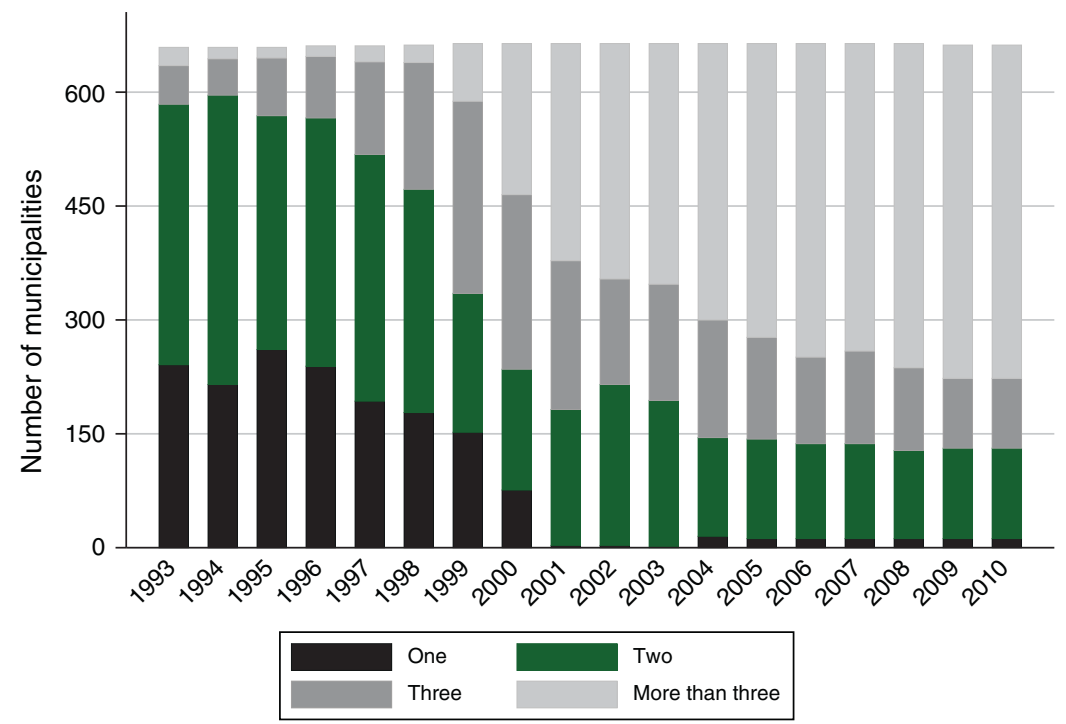

Figure 2. Municipalities by Number of Local Editions

Note: Number of municipalities with one, two, three, or more than three newspaper local editions in a given year.

technological innovations and the overall profitability and competitiveness of the Italian newspaper industry have also been facilitated by a 1985 national legislation in support of the press industry. This legislation involved discounted loans for investments in new technologies, a limit to newspapers concentration of 20 percent of the national market, public subsidies to purchase raw paper, and unemployment benefits to facilitate the reduction of labor costs. ${ }^{7}$

Figure 2 illustrates the expansion of the supply of local news provided by newspapers throughout our sample period. The average number of local news per city provided by newspapers has increased due to the increase in the supply of print editions of local and national newspapers and to the expansion in the number of online editions (see online Appendix Figure A6 for an overview of the market evolution).

At the same time, the online Appendix shows that the pattern of circulation over time does not show any positive trend in readership levels (see Figure A1). Hence, there does not exist any underlying trend suggesting an endogenous increase in the willingness to become informed about political news by Italian citizens.

Finally, as shown in Figure 3, the expansion in the local news provided by newspapers has spread across all Italian provinces. In particular, this increase appears

\footnotetext{
national television stations, which mainly provide national news. In 2008, local television channels accounted for less than 7 percent of the overall TV audience (AGCOM 2009). The Italian radio market is highly fragmented and local radios cover a small market share (Fabbri 2004).

${ }^{7}$ The presence of direct public subsidies to the Italian press industry is not a concern for our empirical strategy. Subsidies are exogenously targeted to specific newspaper categories (e.g., newspapers owned by political parties or by religious organizations). Moreover, the law regulating these subsidies is national and thus it does not affect the geographical variation in the supply of newspapers within Italy.
} 
Panel A. 1993

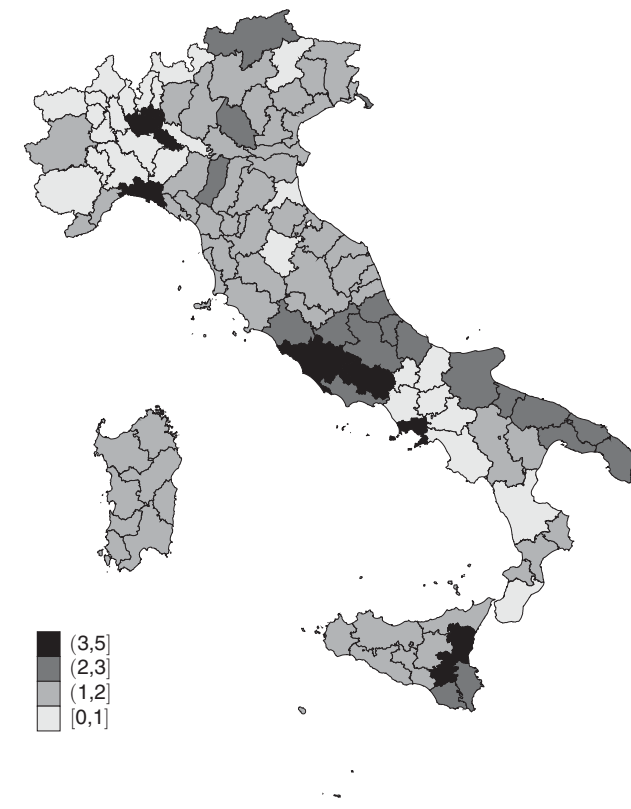

Panel B. 2010 versus 1993

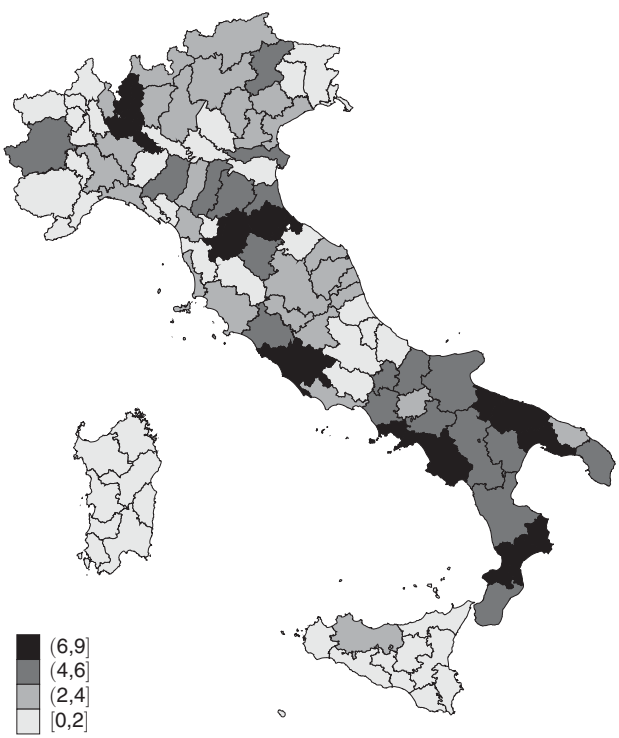

Figure 3. Geographical Distribution of Local Editions

Note: Geographical distribution (per province) of the number of newspaper local editions at the beginning of the sample period (panel A) and geographical distribution of the net change in the number of local editions over the period (panel B).

mostly pronounced in the provinces where there were fewer newspapers providing local news to start with. ${ }^{8}$

\section{E. Drivers of Newspaper Entry and Exit}

In this section we analyze the empirical determinants of newspaper entry and exit based on observable variables. We look at what explains the cross-sectional variation of entry and exit by not absorbing for any fixed effects but year fixed effects, and then by absorbing for city and macro-region-by-year fixed effects (as we do in our empirical analysis). ${ }^{9}$ In particular, we regress the event of entry or exit (a variable equal to 0 if no entry or exit occurs and equal to 1 and -1 otherwise) on the set of observable characteristics, namely, the number of existing newspapers, the log of unemployment rate and population, and the net changes in the number of firms. Table 3 shows the results.

When controlling only for year fixed effects in column 1, socioeconomic variables seem to play a role in the (net) entry of newspapers in a local market for news.

\footnotetext{
${ }^{8}$ In the online Appendix, we show that a similar pattern is observed when controlling for population (see Figure A2). We also show the geographical distribution of changes in readership (see Figure A3).

${ }^{9}$ While we perform this exercise both for the sample used in the empirical analysis, namely for electoral years, and for all years, we present only the results from our sample. When we consider all years, results are very similar and are available upon request.
} 
TABle 3-Drivers of NeWSPAPER ENTRy AND Exit

\begin{tabular}{|c|c|c|c|c|}
\hline & \multicolumn{4}{|c|}{ Newspapers } \\
\hline & $(1)$ & $(2)$ & (3) & (4) \\
\hline Newspapers at $(t-1)$ & $\begin{array}{c}-0.1031 \text { *** } \\
(0.0125)\end{array}$ & $\begin{array}{c}-0.3697 * * * \\
(0.0267)\end{array}$ & $\begin{array}{c}-0.3485^{* * * *} \\
(0.0290)\end{array}$ & $\begin{array}{c}-0.3448 * * * \\
(0.0295)\end{array}$ \\
\hline $\log$ population & $\begin{array}{l}0.1062 * * * \\
(0.0190)\end{array}$ & $\begin{array}{c}0.2543 \\
(0.3560)\end{array}$ & $\begin{array}{c}-0.1153 \\
(0.3019)\end{array}$ & $\begin{array}{c}-0.0850 \\
(0.3055)\end{array}$ \\
\hline log provincial unemployment & $\begin{array}{c}-0.0103 \\
(0.0211)\end{array}$ & $\begin{array}{c}-0.1618^{* *} \\
(0.0711)\end{array}$ & $\begin{array}{r}-0.1176 \\
(0.0812)\end{array}$ & $\begin{array}{c}-0.1138 \\
(0.0829)\end{array}$ \\
\hline Net change number of firms commercial sector & $\begin{array}{l}0.1309 * * \\
(0.0607)\end{array}$ & $\begin{array}{c}0.0103 \\
(0.0811)\end{array}$ & $\begin{array}{c}-0.0391 \\
(0.0848)\end{array}$ & $\begin{array}{c}-0.0408 \\
(0.0868)\end{array}$ \\
\hline Net change number of firms financial sector & $\begin{array}{l}0.1395^{* *} \\
(0.0537)\end{array}$ & $\begin{array}{c}0.0244 \\
(0.0672)\end{array}$ & $\begin{array}{c}0.0255 \\
(0.0722)\end{array}$ & $\begin{array}{c}0.0304 \\
(0.0741)\end{array}$ \\
\hline Mayor's party left & - & - & - & $\begin{array}{c}0.0411 \\
(0.0532)\end{array}$ \\
\hline Mayor's party center & - & - & - & $\begin{array}{c}0.0480 \\
(0.1064)\end{array}$ \\
\hline Mayor's party right & - & - & - & $\begin{array}{c}0.0238 \\
(0.0533)\end{array}$ \\
\hline Binding term limit & - & - & - & $\begin{array}{c}-0.0268 \\
(0.0246)\end{array}$ \\
\hline Year FE & Yes & Yes & No & No \\
\hline City FE & No & Yes & Yes & Yes \\
\hline Macro-region-by-year FE & No & No & Yes & Yes \\
\hline Number of city $\times$ years & 2,168 & 2,168 & 2,168 & 2,133 \\
\hline$R^{2}$ & 0.204 & 0.571 & 0.683 & 0.684 \\
\hline
\end{tabular}

Notes: The table reports the results of a set of regressions where the dependent variable is 1 if the city experienced a net newspaper entry (i.e., net increase in the number of newspaper local editions) between 2 consecutive electoral years (considering both national and local newspapers), -1 if it experiences a net exit, and 0 otherwise. Robust standard errors clustered at the city level are in parentheses.

*** Significant at the 1 percent level.

** Significant at the 5 percent level.

* Significant at the 10 percent level.

In particular, as expected, newspapers entry is positively correlated with population and the net change in the number of firms in the financial and commercial sectors in a given year and negatively correlated with the unemployment rate (although in this case the precision of the coefficient is very limited). Moreover, newspaper entry is significantly and negatively correlated with the number of newspapers present in the city in the previous year, indicating that the competitiveness of the market for local news represents a crucial driver of entry. Interestingly, once we control for city and macro-region-by-year fixed effects in columns 2 and 3, these effects disappear, with the important exception of the number of newspapers present in the city at $(t-1)$. In column 4, we also include political controls. Specifically, a set of dummies indicating the party affiliation of the mayor and a dummy indicating whether the mayor's term limit is binding or not. Results are essentially unchanged, suggesting that local political cycles have a limited impact on newspaper entry and exit.

Overall, these results provide empirical support to the historical evidence discussed in the previous section. If the fixed effects at the city and at the macro-region-by-year 
level control for demand-side factors and the number of newspapers in the previous electoral year controls for supply-side factors, then the remaining variation in the number of newspapers providing local news seems to be driven by structural changes in the supply side (i.e., drop in the production costs) rather than being the result of changes on the demand side. A plausible interpretation is that newspapers entered the market for local news where the local demand for news did not allow them to be profitable in earlier years due to the high production costs. When the production costs started decreasing, the supply of newspapers providing local news increased, even if the demand for local news did not change.

\section{Empirical Strategy}

\section{A. Specification}

Let $y$ be the outcome variable, $i$ the municipality, $h$ the macro-region, $o$ the ownership of the newspaper, and $t$ the electoral year. We assume that the relationship between the outcome variable and the number of newspapers $n$ is captured by the following model:

$$
y_{i t}=\theta_{h t}+\gamma_{i}+\phi_{o t}+\beta \cdot n_{i t}+\mathbf{x}_{i t}^{\prime} \cdot \alpha+\varepsilon_{i t},
$$

where $\theta_{h t}$ are macro-region-by-year fixed effects, $\gamma_{i}$ are city fixed effects, $\phi_{o t}$ are newspaper ownership fixed effects (i.e., for each main editorial group in Italy, there is a dummy variable having value one if there is at least one newspaper belonging to that editorial group in city $i), \mathbf{x}$ is a vector of time-varying control variables at the city or province level (namely, the log rate of provincial unemployment, the log of population at the city level, and the difference between the log of the number of firms created in year $t$ and the log of the number of ceased firms in year $t$ at the province level), and $\beta$ is the the coefficient of interest. ${ }^{10}$ In line with Gentzkow, Shapiro, and Sinkinson (2011), the unobserved component $\varepsilon_{i t}$ is assumed to have the following form:

$$
\varepsilon_{i t}=z_{i t}+u_{i t} \text {, }
$$

where $u_{i t}$ is an idiosyncratic shock and $z_{i t}$ is the profitability of the market for local news in city $i$ in a given electoral year. We estimate model (1) in first differences:

$$
\Delta y_{i t}=\Delta \theta_{h t}+\Delta \phi_{o}+\beta \cdot \Delta n_{i t}+\Delta \mathbf{x}_{i t}^{\prime} \cdot \alpha+\Delta \varepsilon_{i t},
$$

\footnotetext{
${ }^{10}$ The unemployment rate represents a proxy for the level of per capita income. Population size should absorb the variation in the net entry of newspapers driven by changes in population. The difference between new and ceased firms is a measure of the strength of the economy. Ownership fixed effects in a city are likely to control for the ideological slant of newspapers belonging to a given editorial group. Specifically, the editorial groups considered are: Athesis, Caltagirone Editore, Edisud, Editoriale Oggi, Editrice La Stampa, Gruppo Editoriale L'Espresso, Monrif, RCS, and Seesab.
} 
where the city fixed effects disappear and $\Delta \theta_{h t}$ and $\Delta \phi_{o}$ are treated as macro-region and ownership fixed effects. The key variable $\Delta n_{i t}$ is equal to zero if no change in the number of newspapers occurred between $t-1$ and $t$. Instead, we normalize $\Delta n_{i t}$ to be equal to 1 or -1 if city $i$ experienced a net increase or decrease in the number of local news provided by newspapers, respectively. This specification allows us to capture sharper differences (positive, negative, or null) within and across cities in the supply of local news. ${ }^{11}$ At the same time, in Section A, we explicitly investigate how the number of preexisting newspapers in the market for local news interacts with the estimated effects.

\section{B. Identification and Diagnostics}

The empirical challenge in estimating model (3) is that we cannot observe time-varying shocks in newspaper profitability, $\Delta z_{i t}$ in $\Delta \varepsilon_{i t}$. If these shocks are correlated to the electoral outcome $\Delta y_{i t}$, we would obtain a biased estimate of our coefficient of interest $\beta$. Our identifying assumption is that once we control for the large set of time-varying variables and fixed effects, variation in $\Delta n_{i t}$ is orthogonal to the unobserved component $\Delta \varepsilon_{i t}$.

The main argument for identification is that discrete changes in the number of newspapers lead to strong on-impact changes in readership per capita—and in turn on the outcome variables-that are large relative to contemporaneous changes in profitability (see Gentzkow, Shapiro, and Sinkinson 2011 for a detailed discussion). While we will provide several pieces of evidence consistent with this identifying assumption, also note that the results presented in Table 3 support it. Any potential correlation between $\Delta z_{i t}$ and $\Delta n_{i t}$ should translate into a significant and possibly strong correlation between the entry or exit of newspapers and observable variables presumably correlated with $\Delta z_{i t}$ (e.g., population and unemployment). As we have discussed, however, any correlation between the entry of newspapers and socioeconomic variables disappears once we control for macro-region-by-year and city fixed effects.

Another threat to identification is that local politicians may manipulate the presence of newspapers providing local news to be reelected. At the national level, politicians' control over the media represents a serious concern, especially in Italy. However, at the local level, this does not seem to be the case. Most of the newspapers in our sample are headquartered in cities different from those where local editions actually take place, and are thus unlikely to be captured by local politicians. ${ }^{12}$ Moreover, as shown by Table 3 (and by Figures A5a and A5b in the online Appendix), political variables, and especially the presence of incumbent mayors up for reelection, are not significantly correlated with newspaper entry and exit. This evidence is consistent with the results of Gentzkow et al. (2012) showing that the influence of incumbent politicians on the US press in 1869-1928 was extremely limited.

\footnotetext{
${ }^{11}$ Results are robust to alternative definitions of $\Delta n_{i t}$, such as the exact difference in the number of total newspapers (available upon request).

${ }^{12}$ Our main results are also robust to restricting the analysis to variation in the supply of local news occurring when the incumbent mayor is term-limited (available upon request).
} 
In addition to the above arguments, a crucial validity test of our identification strategy is to assess the absence of any pretrend in the outcome variables. If unobserved shocks to the profitability of the market for local news affect political outcomes (or are driven by the same factors), we should observe past changes in the supply of local news to be correlated with current changes in political outcomes, or vice versa. We check for the existence of pretrends in several ways. As in Gentzkow, Shapiro, and Sinkinson (2011), we reestimate the model in first differences, including leads and lags of newspaper entry and exit:

$$
\Delta y_{i t}=\Delta \theta_{h t}+\Delta \phi_{o}+\sum_{k=-2}^{k=2} \beta^{k} \cdot \Delta n_{i(t-k)}+\Delta \mathbf{x}_{i t}^{\prime} \cdot \alpha+\Delta \varepsilon_{i t}
$$

Here, $\beta_{0}$ is the equivalent of the instantaneous treatment effect $\beta$ in model (3). The coefficients $\beta^{k}$ with $k<0$ test for the existence of pretrends, as they reflect the relationship between current changes in the number of newspapers and past changes in the outcomes. To validate our identifying assumption, we expect these coefficients not to be statistically different from zero. The coefficients $\beta^{k}$ with $k>0$ capture dynamic treatment effects (if any), as they reflect the relationship between current changes in the number of newspapers and future changes in the outcomes. Because the cities in our sample are observed, on average, for 4.3 electoral terms (minimum 3 , maximum 7), we can estimate equation (4) only on a small subsample of our data. Therefore, in order to increase sample size and to be conservative, we also estimate the coefficient of each $\Delta n_{i(t-k)}$ in a separate regression; in other words, we reestimate model (3) by replacing $\Delta n_{i(t k)}$ with each $\Delta n_{i(t-k)}$ in turn. These validity tests are reported in Section VII. ${ }^{13}$

Finally, in the online Appendix, we assess to what extent our baseline estimates may be due to random chance, as opposed to a true causal effect, by performing placebo tests based on the simulation of false entries and exits. We select a subsample of municipalities that never experienced either newspaper entry or exit, and we randomly assign false entry and exit episodes, according to the shares of entry and exit observed in the other municipalities. We then estimate the treatment effect of these false episodes (which on average should be zero) and repeat the estimation 10,000 times. By plotting the cumulative distribution function of these simulations, we expect to observe only a few false effects (e.g., less than 5 percent) to be larger than the true baseline estimate in absolute value.

\footnotetext{
${ }^{13}$ In the online Appendix, we perform two additional robustness checks. First, we exploit the yearly variation in our data-as opposed to the variation by electoral term exploited in equation (4)—and estimate a version of model (4) using annual leads and lags within the electoral term affected by the newspaper entry or exit (with $k$ ranging from -3 to 3 in this case, as electoral terms lasted 4 years for most of our sample period). Second, we evaluate whether the number of newspapers in city $i$ and year $t$ is correlated with our outcomes in the previous elections by estimating an equation analogous to model (1):
}

$$
n_{i t}=\theta_{h t}+\gamma_{i}+\phi_{o}+\pi_{t-\tau} \cdot y_{i(t-\tau)}+\mathbf{x}_{i t}^{\prime} \cdot \alpha+\varepsilon_{i t} .
$$

To rule out confounding pretrends, we expect $\pi_{t-\tau}$, for $\tau=1,2,3$, not to be statistically different from zero. 


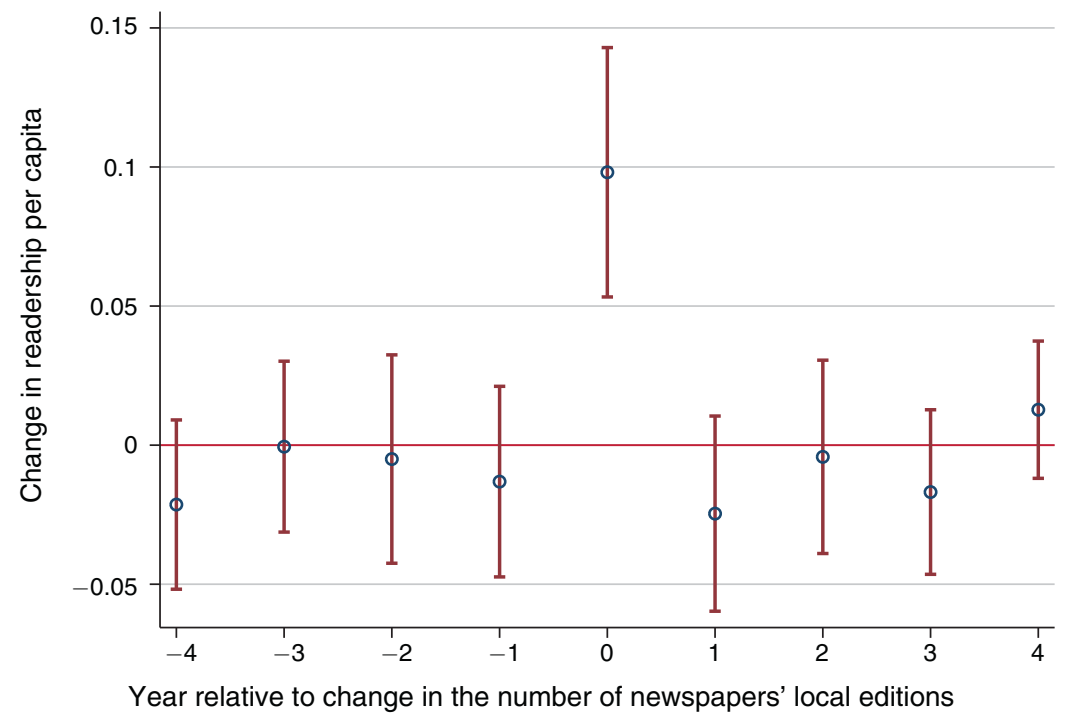

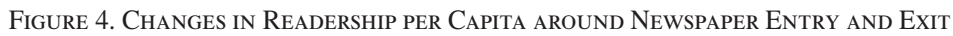

Notes: Dependent variable: readership per capita at the province level. Regression coefficients of four (yearly) leads and four (yearly) lags with respect to the year of entry of a (print) newspaper local edition. Entry is expressed as the provincial weighted average (by population) of entry per capita. Bars represent 95 percent confidence intervals. Standard errors are clustered by province. All years from 1993 to 2010 .

\section{Newspapers and Electoral Outcomes}

\section{A. Electoral Participation}

In this section, we focus on voters' electoral participation in municipal elections. As a first step, we also look at the effect of an expansion in the supply of local news on readership per capita. Since readership data are available only at the province level, we use the weighted average of newspaper entry in all the cities belonging to a given province. ${ }^{14}$ Figure 4 illustrates how readership evolves around the time of an expansion in the number of local news supplied by newspapers, by estimating the analog of equation (4) on annual readership data. ${ }^{15}$ Here, we focus on the effect on readership of an expansion of local news provided by print newspaper editions, so as to ensure consistency between the dependent and the explanatory variable.

As shown by the estimated coefficients in Figure 4, an increase in the supply of newspapers providing local news has a large positive impact on readership of around 10 percentage points. Moreover, the effect occurs on impact. That is, dynamic effects after the event are small relative to the instantaneous effect of the event. The estimates also show that there is no trend in per capita demand for newspapers prior

\footnotetext{
${ }^{14}$ Specifically, entry is expressed in terms of the provincial weighted average of entry per capita; weights correspond to the ratio of the municipal population over the provincial population.

${ }^{15}$ Note that in this figure, unlike equation (4), the time dimension refers to all the years in the sample (i.e., 1993-2010), since the sample of electoral years would not have allowed us to estimate the specification with 4 leads and 4 lags (given that each city experiences, on average, only 4.3 elections).
} 
TABLE 4-NewsPapers, ReAdership, ANd Electoral Outcomes

\begin{tabular}{lcccc}
\hline \hline & $\begin{array}{c}\text { Readership } \\
(1)\end{array}$ & $\begin{array}{c}\text { Turnout } \\
(2)\end{array}$ & $\begin{array}{c}\text { Rerun for office } \\
(3)\end{array}$ & $\begin{array}{c}\text { Reelected } \\
(4)\end{array}$ \\
\hline Newspapers & $0.0583^{* * *}$ & $0.0045^{* * *}$ & 0.0763 & $0.1076^{* *}$ \\
& $(0.0122)$ & $(0.0017)$ & $(0.0485)$ & $(0.0535)$ \\
Number of province $\times$ years & 1,712 & & & \\
Number of provinces & 110 & & & \\
Number of city $\times$ years & & 2,014 & 924 & 546 \\
Number of cities & & 658 & 644 & 486 \\
$R^{2}$ & 0.1233 & 0.6195 & 0.1761 & 0.2232 \\
\hline
\end{tabular}

Notes: Models are estimated in first differences-see equation (3) in the text. All specifications include macro-region-by-year and ownership fixed effects, log of population, log of changes in the number of new and ceased firms in the commercial and financial sector, and log of the unemployment rate. The dependent variable in column 1 is defined at the province level, while in columns $2-4$ it is defined at the city level. Column 3 reports the results of the model estimated by conditioning the regression on electoral terms where the mayor's term limit is not binding. Column 4 reports the results of the model estimated by conditioning the regression on electoral terms where the mayor decided to rerun for office. Robust standard errors in parentheses are clustered by province for column 1 and by city for columns 2-5.

*** Significant at the 1 percent level.

** Significant at the 5 percent level.

* Significant at the 10 percent level.

to the event, that is, before the entry of a newspaper in the market. If anything, readership per capita declines before entry. ${ }^{16}$ Column 1 of Table 4 reports the estimate of model (3) with readership per capita as outcome. Again, units of observation are 110 Italian provinces in this case. "Newspapers" refers to the coefficient of newspaper entry and exit, $\Delta n_{i t}$. Consistently with Figure 4, the estimated coefficient is positive and significant both in statistical and economic terms.

Column 2 of Table 4 reports the estimate of model (3) where $\Delta y_{i t}$ represents the difference between the turnout rate in municipal election in city $i$ and year $t$ relative to the turnout rate in the same city and electoral year $t-1$. Now, the units of observations are all 2,014 elections in our dataset. The results show that the entry of newspapers increases turnout by 0.45 percentage points (about 0.6 percent with respect to the average turnout).

To assess the magnitude of the effects with respect to the existing literature, we compute the corresponding persuasion rate (see DellaVigna and Kaplan 2007). Within our context, the persuasion rate represents the number of individuals who changed their turnout decision following newspaper entry, as a fraction of all individuals who could have changed their behavior. To properly compute this statistics, we need to compare homogeneous newspaper categories. Since our readership data refer only to newspaper print editions, a proper assessment of the persuasion rate requires to estimate the effect of newspaper print editions on both readership and turnout. Section VIB shows that the entry of a newspaper print edition increases turnout by 0.47 percentage points and readership per capita by 11 percentage points.

\footnotetext{
${ }^{16}$ These patterns are robust to limiting the analysis to the subset of newspapers with certified provincial readership data (see Figure A4 in the online Appendix).
} 
Since the average turnout in city-years not experiencing an increase in the supply of local news is equal to 77 percent, 23 percent of eligible voters could be "persuaded" by the entry of a newspaper. Moreover, within the population of those who would abstain absent newspaper entry, 11 percent read a newspaper, representing 2.53 percent of all eligible voters (implicitly assuming that voters are as likely as non-voters to read newspapers). Hence, the 0.47 percent of voters who vote following the expansion in the supply of local news corresponds to a persuasion rate of $(0.47 / 0.0253)=18.6$ percent. The size of this effect is close to the highest value found in the literature on voters' persuasion (DellaVigna and Gentzkow 2010) and similar to other works estimating the effect of local news on turnout (Oberholzer-Gee and Waldfogel 2010). Indeed, as we estimate the effect of local news on local elections (i.e., we define the news market to be a city), the news analyzed in our study is likely to be more salient than those investigated in previous studies.

\section{B. Incumbent Mayor's Reelection}

Column 3 in Table 4 reports the estimated effect of newspaper entry and exit on the probability of the incumbent mayor deciding to run for her second term. Here, $\Delta y_{i t}$ represents the difference between the decision of the incumbent mayor in city $i$ and year $t$ to run for reelection with respect to the analogous decision of the previous incumbent mayor. There is some evidence that this probability increases with the entry of new sources of local news. The expansion of local news increases the probability to run for a second term by 7.63 percentage points, corresponding to about a 13 percent increase relative to the average. However, the coefficient is imprecisely estimated and not statistically different from zero.

Column 4 shows the effect of newspaper entry and exit on the probability of the incumbent mayor being reelected (conditional on rerunning for office). In this case, the effect of local news is not only positive, but also statistically different from zero. The entry of newspapers increases the difference in the incumbent's probability of reelection by 10.76 percentage points, corresponding to a 14 percent increase relative to the average.

Clearly, the positive impact of newspapers on the incumbent's reelection may be due to alternative channels with different implications for voters' welfare. Newspapers may be captured by incumbent politicians and used as "lap-dogs" (e.g., see Di Tella and Franceschelli 2011). However, as discussed by Besley and Prat (2005), the higher the number of news sources, the harder for incumbent politicians to capture media outlets, because hiding political scandals would require them to suppress news from all media. Hence, our average positive effect of newspaper entry on the incumbent's reelection probability is unlikely to be due to media capture alone, especially if this effect persists as competition increases (see Section VIA). At the same time, an increase in the supply of news is likely to increase the visibility of politicians in office, and it may make it easier for the good ones to signal their type. It may also enhance the accountability of incumbents and thus increase their effort.

To disentangle between the multiple channels linking newspapers, politicians, and public policy, the remaining part of our analysis addresses three complementary 
research questions. First, in Section IV, we investigate whether newspaper entry has an impact on the mayor's type (i.e., on the observable characteristics of mayors). In Section V, we tackle the issue of newspapers' influence on the mayor's effort by exploring how entry affects local government efficiency, and we also investigate the role of term limits. Third, in Section VIA, we study the role of media competition by looking at possible nonlinearities in the effects.

\section{Newspapers and Political Selection}

This section evaluates the effect of changes in the supply of newspapers providing local news on the characteristics of elected politicians. The main advantage of our study with respect to the existing literature is to have direct measures of politicians' characteristics. ${ }^{17}$ In particular, we look at the mayor's gender, age, years of schooling, and previous employment status. These variables allow us to assess the extent of newspaper influence on political selection along several dimensions. In the ranking of women in national parliaments, Italy is at the fifty-first place worldwide and at the twenty-fourth place (out of 27) within Europe (Inter-Parliamentary Union (IPU) 2011). In municipal governments, women account for only 7 percent of mayors. At the same time, Italy is widely considered as a "gerontocracy" given the high average age of politicians (e.g., the average age of mayors is about 50 years old). Female and young candidates typically represent the "underdogs" in electoral races. Thus, analyzing the effect of newspapers on mayor's gender and age may provide evidence on whether an increase in the supply of local news lowers the barriers to entry into political representation. Years of schooling, instead, are commonly used as a measure of the quality of politicians (e.g., Merlo et al. 2010; Galasso and Nannicini 2011). Finally, previous employment status may capture idiosyncratic skills along the competence dimension. Table 5 shows the estimation results.

The estimates show that there is no compelling evidence of any effect of newspapers on the mayor's characteristics. The coefficients are small in size and imprecisely estimated. Overall, while a change in the supply of local news has an effect on turnout and on the incumbent's reelection probability, it does not affect the (observable) characteristics of elected politicians, that is, their type. ${ }^{18}$ At the same time, even if the characteristics of elected mayors analyzed here capture a wide range of personal attributes, it might still be the case that newspapers have an effect on (unobservable) characteristics of elected mayors orthogonal to those we use. In order to investigate this issue further, Section VB uses term limit to disentangle whether the effect of newspapers on government efficiency (if any) is likely to be due to the impact of newspapers on the mayor's type or effort.

\footnotetext{
${ }^{17}$ Snyder and Strömberg (2010) control for politicians' fixed effects to isolate incentives from selection in their regressions. They show that their results are essentially unchanged to the inclusion of fixed effects (with the exception of party loyalty). They do not focus, however, on politicians' observable characteristics.

${ }^{18}$ Indeed, also in the sample under analysis (which is a subsample of the one considered in Section IIIA because of missing values in politicians' observable characteristics), we observe a positive effect of local news on electoral turnout (results available upon request).
} 
Table 5-Newspapers and Politicians' Selection

\begin{tabular}{lcccc}
\hline \hline & Female & Age & Years of schooling & Not employed \\
& $(1)$ & $(2)$ & $(3)$ & $(4)$ \\
\hline Newspapers & -0.0162 & -0.4339 & 0.0212 & 0.0043 \\
& $(0.0147)$ & $(0.5725)$ & $(0.1329)$ & $(0.0144)$ \\
Number of city $\times$ years & 1,837 & 1,837 & & 1,837 \\
Number of cities & 657 & 657 & 657 & 1,837 \\
$R^{2}$ & 0.0574 & 0.0533 & 0.0466 & 657 \\
& & & 0.0569 \\
\hline
\end{tabular}

Notes: Models are estimated in first differences-see equation (3) in the text. All specifications include macro-region-by-year and ownership fixed effects, log of population, log of changes in the number of new and ceased firms in the commercial and financial sector, and log of the unemployment rate. Robust standard errors clustered at the city level are in parentheses.

*** Significant at the 1 percent level.

** Significant at the 5 percent level.

* Significant at the 10 percent level.

\section{Newspapers and Public Policy Outcomes}

\section{A. Local Government Efficiency}

The above results show that the entry of newspapers increases electoral participation and improves the reelection chances of the incumbent mayor, but does not affect mayor's (observable) characteristics. A crucial issue at this point is whether newspapers affect the performance of local governments, in order to assess whether the higher reelection probability of incumbent mayors can be attributed to an improvement in their effort or not.

To address this issue, we evaluate the impact of newspaper entry and exit on two indicators of local government efficiency: the average speed of revenue collection and the average speed of payments during the mayoral term. These measures are commonly used as efficiency benchmarks both in policy analysis (e.g., ANCI 2012) and in the scientific literature (e.g., Gagliarducci and Nannicini 2013) for several reasons. With respect to taxes, the speed of revenue collection is expected to increase if the local government is able to fight tax evasion, which is a compelling problem for government effectiveness in Italy. Moreover, with respect to transfers, the speed of revenue collection is expected to increase if the local government is effective in implementing centrally financed public works, so as to receive new blocks of capital transfers. The speed of payments is instead expected to increase if the local government is effective in meeting its promises of payment to private contractors.

The sample of city-years where we assess the effect of newspapers on local government efficiency contains a limited number of observations (compared with the sample on electoral participation) for two reasons. First, these measures are available only for a subset of cities (around 574). Second, these measures are available only for the period 1993-2007. We estimate model (3), where $\Delta y_{i t}$ represents the difference between each efficiency measure during the electoral term starting in year $t$ with respect to the previous term.

Columns 1 and 2 in Table 6 report the estimation results for the two efficiency measures in the all sample. Although statistical accuracy is hampered by the small 
TABle 6-NewsPaPers AND GovernMENT EFFICIENCY

\begin{tabular}{lcccc}
\hline \hline & $\begin{array}{c}\text { Speed of } \\
\text { collection } \\
(1)\end{array}$ & $\begin{array}{c}\text { Speed of } \\
\text { payments } \\
(2)\end{array}$ & $\begin{array}{c}\text { Speed of } \\
\text { collection } \\
(3)\end{array}$ & $\begin{array}{c}\text { Speed of } \\
\text { payments } \\
(4)\end{array}$ \\
\hline Newspapers & $2.1636^{* *}$ & -0.0198 & $4.6599^{* * * *}$ & 0.1617 \\
& $(1.0851)$ & $(0.4591)$ & $(1.5045)$ & $(0.6462)$ \\
Number of city $\times$ years & 964 & 964 & 559 & 559 \\
Number of cities & 574 & 574 & 478 & 478 \\
$R^{2}$ & 0.5647 & 0.1464 & 0.5450 & 0.1814 \\
\hline
\end{tabular}

Notes: Models are estimated in first differences - see equation (3) in the text. All specifications include macro-region-by-year and ownership fixed effects, log of population, log of changes in the number of new and ceased firms in the commercial and financial sector, and log of the unemployment rate. Columns 1-2 use the all sample. Columns 3-4 report the results of the model estimated by conditioning the regressions on electoral terms where the mayor's term limit is not binding. Robust standard errors clustered at the city level are in parentheses.

*** Significant at the 1 percent level.

** Significant at the 5 percent level.

* Significant at the 10 percent level.

number of observations, the estimates show that an increase in the supply of local news improves the efficiency of municipal governments. In particular, the speed of revenue collection increases by 2.16 percentage points, which represents a 3 percent increase with respect to the average value of this efficiency indicator. At the same time, it is not possible to make an inference on the effect of newspapers on the speed of payments, because the estimated coefficients are associated with very large standard errors.

Our result on revenue collection is consistent with the evidence provided by Casaburi and Troiano (2012), who show that Italian mayors have a higher probability of being reelected when they are effective in fighting tax evasion. ${ }^{19}$ Also in our case, it seems that voters tend to reward incumbent mayors for their increased effort in this respect. On the whole, our results suggest that an expansion in the supply of local news increases the accountability of elected politicians. ${ }^{20}$ This shows that newspapers may play a positive role on citizens' welfare even when they do not increase their electoral participation. Indeed, the increase in electoral turnout only reflects the increase in the level of information of citizens who abstained in the previous election. An expansion in the supply of local news, however, is also very likely to increase the level of information of those who already voted in the previous election. This may translate into a higher level of local government efficiency for two distinct reasons. First, the higher level of citizens' information may lead to a better selection of politicians. That is, it may improve the competence of elected politicians along dimensions that are not captured by (and are orthogonal

\footnotetext{
${ }^{19}$ A standard deviation of their measure of reduced tax evasion increases the incumbent mayor's reelection probability by 2.2 percentage points. In our case, absent any other direct effect of newspaper entry on reelection (which are on the contrary likely to be first order), one more percentage point of speed of collection would increase reelection by 4.4 percentage points. It is therefore plausible that tax evasion is only one of the multiple channels linking newspaper entry, government efficiency, and incumbent's reelection.

${ }^{20}$ Interestingly, this effect seems to go beyond the impact of newspapers on electoral participation. Indeed, in the subsample of city-years used for the estimates of Table 6, the effect of the entry of newspapers on turnout is small and not statistically significant (results available upon request).
} 
to) the observable characteristics analyzed in Section IV. Second, the higher level of citizens' information may improve the accountability of elected politicians and increase their incentive to exert effort.

In order to better disentangle between these two channels-unobservable selection versus reelection incentives - the next section analyzes how newspapers affect the effort of the incumbent mayor when she is in her first electoral term (i.e., when she faces reelection incentives), and then compares the results with those discussed in this section.

\section{B. Selection versus Incentives}

Columns 3 and 4 of Table 6 replicate the analysis of the previous section for the subsample of electoral terms where the mayor's term limit is not binding. The results illustrate two main points. First, the effect of newspapers on local government efficiency when incumbent mayors face reelection incentives is more statistically significant than the one obtained when considering both first and second terms (despite the fact that the sample contains a smaller number of observations). Second, the size of the effect on the speed of revenue collection is more than double the effect estimated in the previous section for all mayors. In the subsample of nonbinding electoral terms, an expansion in the supply of local news increases the speed of revenue collection by 4.66 percentage points, corresponding to a 7 percent increase relative to the average.

From a theoretical point of view, the above results implicitly point in the direction of a mechanism where voters interpret the high effort of mayors during their first term as a signal of their competence. Indeed, given that rational voters anticipate that a term-limited mayor in the next period would exert zero effort, they should reward the incumbent mayor's effort only if it represented a signal of her idiosyncratic skills. Hence, an increase in the supply of local news should have a positive impact both on the incumbent mayor's effort in her first term and on the expected competence of reelected mayors. In the online Appendix, we present a simple theoretical framework summarizing this mechanism.

Furthermore, the higher significance and larger magnitude of the effect of newspapers on government efficiency when the incumbent mayor is not term-limited, together with the insignificant effect of newspapers on the observable characteristics of politicians, suggest that incentives represent the main channel linking newspapers to public policy outcomes.

\section{Decomposing the Effects}

\section{A. Decomposition by Market Structure}

The above results show that newspaper entry and exit have a relevant impact on the behavior of voters and politicians. The entry of newspapers in the market for local news has a positive effect on electoral participation, on the reelection probability of incumbent mayors, and on the efficiency of local governments. At this point, a natural question that needs to be addressed concerns the role played by competition. 
Table 7-Relevant Effects by Number of (Preexisting) Newspapers

\begin{tabular}{lcccc}
\hline \hline & $\begin{array}{c}\text { Turnout } \\
(1)\end{array}$ & $\begin{array}{c}\text { Reelected } \\
(2)\end{array}$ & $\begin{array}{c}\text { Speed of } \\
\text { collection } \\
(3)\end{array}$ & $\begin{array}{c}\text { Speed of } \\
\text { collection } \\
(4)\end{array}$ \\
\hline City has one newspaper & 0.0055 & 0.1337 & $3.6895^{*}$ & $4.7940^{*}$ \\
& $(0.0035)$ & $(0.1167)$ & $(2.1903)$ & $(2.7346)$ \\
City has two newspapers & $0.0066^{* * *}$ & $0.1365^{* *}$ & $2.4779^{*}$ & $5.2125^{* * *}$ \\
& $(0.0022)$ & $(0.0646)$ & $(1.3291)$ & $(1.9980)$ \\
City has three newspapers & 0.0050 & 0.0496 & -0.6881 & 4.0048 \\
& $(0.0036)$ & $(0.0940)$ & $(2.3171)$ & $(2.8306)$ \\
Number of city $\times$ years & 2,014 & 546 & 964 & 559 \\
Number of cities & 658 & 486 & 574 & 478 \\
$R^{2}$ & 0.6252 & 0.2280 & 0.5665 & 0.5474 \\
\hline
\end{tabular}

Notes. Models are estimated in first differences-see equation (3) in the text-with interaction terms between indicators of the number of newspapers in the previous electoral term and the main variable of interest $\Delta n_{i t}$. The rows report linear combinations between the coefficients of the number of newspapers in the previous term and of $\Delta n_{i t}$. All specifications include macro-region-by-year and ownership fixed effects, log of population, log of changes in the number of new and ceased firms in the commercial and financial sector, and log of the unemployment rate. Columns 3-4 report the results for the speed of revenue collection for the all sample and for the subsample of electoral terms where the term limit of the incumbent mayor is not binding, respectively. Robust standard errors clustered at the city level are in parentheses.

*** Significant at the 1 percent level.

** Significant at the 5 percent level.

* Significant at the 10 percent level.

That is, it is important to qualify the above results with respect to the existing degree of competition in the market for local news. Is newspaper entry important only when there are no (or very few) sources of news to start with? Or is the expansion in the supply of newspapers relevant regardless of the preexisting degree of competition?

To analyze this issue, we augment equation (3) by including a set of interactions between $\Delta n_{i t}$ and dummy indicators for the number of preexisting newspapers at $(t-1)$ in city $i$. Since there are very few cities with no newspapers at the beginning of the sample period, we look at differences among cities in which the number of preexisting newspapers is larger or equal to one. Table 7 reports the results.

In columns 1 and 2, the dependent variables are the difference in turnout and in the mayor's reelection outcome conditional on rerunning, respectively. In columns 3 and 4 , we use the difference in the speed of collection for all electoral terms and for the subsample of electoral terms where term limit is not binding, respectively. The table reports the linear combinations between our main variable $\left(\Delta n_{i t}\right)$ and the interaction terms between $\Delta n_{i t}$ and the dummies indicating the number of preexisting newspapers at $(t-1)$. The impact of newspaper entry in the market for local news on political and public policy outcomes does not decrease with the number of preexisting newspapers; it is about the same if the city had one, two, or three newspapers in the previous electoral term-with just one exception in column 3 for government efficiency in the all sample.

In particular, the results on reelection and on the speed of revenue collection point out that media capture by the incumbent mayor is unlikely to be the mechanism behind our overall results. Otherwise, we would expect the positive effect on the incumbent's reelection to vanish as media competition increases. Instead, the 
Table 8-Relevant Effects by Newspaper Type

\begin{tabular}{|c|c|c|c|c|c|}
\hline & $\begin{array}{l}\text { Readership } \\
\text { (1) }\end{array}$ & $\begin{array}{l}\text { Turnout } \\
\text { (2) }\end{array}$ & $\begin{array}{c}\text { Reelected } \\
\text { (3) }\end{array}$ & $\begin{array}{c}\text { Speed of } \\
\text { collection } \\
(4)\end{array}$ & $\begin{array}{l}\text { Speed of } \\
\text { collection } \\
(5)\end{array}$ \\
\hline \multicolumn{6}{|l|}{ Panel A } \\
\hline Print editions & $\begin{array}{l}0.111 * * * \\
(0.0216)\end{array}$ & $\begin{array}{l}0.0047 * * * \\
(0.0015)\end{array}$ & $\begin{array}{c}0.0849 * \\
(0.0478)\end{array}$ & $\begin{array}{c}1.1383 \\
(1.0369)\end{array}$ & $\begin{array}{l}3.7863^{* * * *} \\
(1.3726)\end{array}$ \\
\hline Online editions & $\begin{array}{c}0.0117 \\
(0.0114)\end{array}$ & $\begin{array}{c}0.0016 \\
(0.0023)\end{array}$ & $\begin{array}{c}0.0795 \\
(0.0627)\end{array}$ & $\begin{array}{l}3.3926^{* * * *} \\
(1.1562)\end{array}$ & $\begin{array}{l}3.9059 * * \\
(1.5397)\end{array}$ \\
\hline$p$-value of difference & 0.0001 & 0.2487 & 0.9440 & 0.0837 & 0.9474 \\
\hline$R^{2}$ & 0.123 & 0.6197 & 0.2208 & 0.5667 & 0.5474 \\
\hline \multicolumn{6}{|l|}{ Panel B } \\
\hline Local newspapers & $\begin{array}{l}0.0626 * * * \\
(0.0130)\end{array}$ & $\begin{array}{l}0.0051 * * * \\
(0.0017)\end{array}$ & $\begin{array}{c}0.0735 \\
(0.0527)\end{array}$ & $\begin{array}{c}1.0925 \\
(1.1414)\end{array}$ & $\begin{array}{l}3.5500 * * \\
(1.5244)\end{array}$ \\
\hline National newspapers & $\begin{array}{c}-0.0141 \\
(0.0208)\end{array}$ & $\begin{array}{c}0.0011 \\
(0.0037)\end{array}$ & $\begin{array}{c}0.0511 \\
(0.1045)\end{array}$ & $\begin{array}{c}2.8562 * \\
(1.4589)\end{array}$ & $\begin{array}{c}1.3692 \\
(1.9152)\end{array}$ \\
\hline$p$-value of difference & 0.0026 & 0.3345 & 0.8500 & 0.3445 & 0.3732 \\
\hline$R^{2}$ & 0.117 & 0.6199 & 0.2201 & 0.5641 & 0.5410 \\
\hline \multicolumn{6}{|l|}{ Panel C } \\
\hline New newspapers & $\begin{array}{l}0.0868 * * * \\
(0.0220)\end{array}$ & $\begin{array}{l}0.0041^{* *} \\
(0.0018)\end{array}$ & $\begin{array}{c}0.0499 \\
(0.0677)\end{array}$ & $\begin{array}{c}0.3483 \\
(1.5505)\end{array}$ & $\begin{array}{c}3.7159 * \\
(2.1275)\end{array}$ \\
\hline Existing newspapers & $\begin{array}{l}0.0517 * * * \\
(0.0144)\end{array}$ & $\begin{array}{l}0.0042 * * \\
(0.0017)\end{array}$ & $\begin{array}{c}0.0809 \\
(0.0499)\end{array}$ & $\begin{array}{l}3.2602 * * * \\
(1.0557)\end{array}$ & $\begin{array}{l}5.6756^{* * * *} \\
(1.4189)\end{array}$ \\
\hline$p$-value of difference & 0.1683 & 0.9797 & 0.6835 & 0.1052 & 0.4439 \\
\hline$R^{2}$ & 0.118 & 0.7137 & 0.2208 & 0.5678 & 0.5534 \\
\hline Number of province $\times$ years & 1,712 & & & & \\
\hline Number of provinces & 110 & & & & \\
\hline Number of city $\times$ years & & 2,014 & 546 & 964 & 559 \\
\hline Number of cities & & 658 & 486 & 574 & 478 \\
\hline \multicolumn{6}{|c|}{$\begin{array}{l}\text { Notes: Models are estimated in first differences-see equation }(3) \text { in the text. The effects } \\
\text { are estimated by decomposing the entry/exit variable }\left(\Delta n_{i t}\right) \text { in print versus online editions } \\
\text { (panel A), local versus national newspapers (panel B), and new versus preexisting newspapers } \\
\text { (panel C). In each panel, } p \text {-value of difference refers to the } p \text {-value of a Wald test on the null } \\
\text { hypothesis that the difference of the estimates in the two subsamples is equal to zero. All spec- } \\
\text { ifications include macro-region-by-year and ownership fixed effects, log of population, log of } \\
\text { changes in the number of new and ceased firms in the commercial and financial sector, and log } \\
\text { of the unemployment rate. Robust standard errors in parentheses are clustered by province for } \\
\text { column } 1 \text { and by city for columns } 2-5 \text {. } \\
\text { *** Significant at the } 1 \text { percent level. } \\
\quad * * \text { Significant at the } 5 \text { percent level. } \\
\quad * \text { Significant at the } 10 \text { percent level. }\end{array}$} \\
\hline
\end{tabular}

beneficial effects of increasing newspaper competition (i.e., of allowing more media outlets to enter the market for local news) are relevant even when there are already other newspapers supplying local news.

\section{B. Decomposition by Newspaper Type}

In Table 8, we decompose the relevant effects detected above by type of newspaper. Our dataset allows us to explore different dimensions. In particular, we can distinguish between the net entry of a newspaper print edition and the net entry 
of a newspaper online edition (panel A); between local and national newspapers (panel B); or between newspapers already circulating in the city and new newspapers entering the market for local news (panel C). In each panel, the two (net) entry variables sum up to the (net) entry variable referring to any type of newspaper used in the previous sections. For each decomposition, we also report the $p$-value of a Wald test on the null hypothesis that the difference between the estimates in the two subsamples is equal to zero.

Print versus Online Editions.-Panel A of Table 8 suggests that the print editions of newspapers providing local news have a larger impact than online editions, although the differences (with the obvious exception of readership) are generally insignificant at standard levels. Indeed, an expansion in the supply of local news due to an increase in print editions corresponds to an increase in the number of local news sources. Instead, online editions typically provide contents that are similar to their offline counterparts while lowering the cost of obtaining news. Our results indicate that both components play a relevant role, although the expansion in local news sources is likely to be the dominant channel. ${ }^{21}$

Local versus National Newspapers.-Panel B of Table 8 shows that local newspapers have a positive and significant impact on newspapers' readership, on electoral turnout, and on local government efficiency (especially when the incumbent mayor is not term limited). Point estimates for national newspapers are also positive and not statistically different from those of local newspapers (with the exception of readership), but they are smaller in size and not precisely estimated. As shown by the market structure transition matrices by newspaper type presented in the online Appendix (see Tables A3a-A3f), the variation in national newspaper entry and exit is limited compared to other newspaper categories and especially to local newspapers. As a result, the lower precision of the estimated coefficients for national newspapers might be due to the lower power of the test. Yet, it is tempting to speculate on the potential theoretical mechanisms behind the above differences.

While an increase in the number of local newspapers providing local news is likely to increase the number of voters informed on local politics, this may not be necessarily the case with national newspapers. Throughout our sample, national newspapers typically open a local edition in cities where incumbent local newspapers are already providing local news. This is relevant because local newspapers typically cover political as well as nonpolitical information (e.g., weather forecasts, pharmacies' schedule, obituaries, movie theaters listing, etc.). Readers mainly interested in local nonpolitical information have to buy a local newspaper to get this type of information, in the absence of a national newspaper providing it. Hence, these readers may become informed about local politics as a by-product of buying the local newspaper. ${ }^{22}$ When a national newspaper enters the market for local news, some of these readers may switch from the local to the national newspaper.

\footnotetext{
${ }^{21}$ In online Appendix Table A1, we show that our baseline results are not sensitive to dropping online entries that are contemporaneous to the creation of print editions.

${ }^{22}$ See Downs (1957); Popkin (1991); and Prior (2007) for theories on by-product learning.
} 
As a result, they may turn their attention away from local politics (e.g., spending more time reading about national politics). Their electoral participation in municipal elections may thus decrease (i.e., there may be a crowding-out effect of national newspapers as in George and Waldfogel 2008). At the same time, the introduction of a national newspaper's local edition increases the supply of local news offered to its readers, and their electoral participation may increase. At the end of the day, the overall (net) effect of the entry of national newspapers may be positive, negative, or null depending on the extent of these two opposite effects. Overall, our results point out that the combined effect is not statistically different from zero. ${ }^{23}$

Existing versus New Newspapers.-Finally, panel C of Table 8 shows that the opening of local editions by existing newspapers and the arrival of new newspapers display similar effects, although the impact of existing newspapers on policy outcomes is relatively larger. Indeed, the extra provision of local news by both existing and new newspapers is likely to raise voters' level of information through an increase in readership (extensive margin). At the same time, the extra provision of local news by existing newspapers is also likely to affect voters who were already reading those newspapers in the absence of local news (intensive margin). In online Appendix Table A2, we further decompose local, national, and existing newspapers by looking at whether their net entry involved a print or an online edition, detecting consistent results.

\section{Validity Tests}

In this section, we empirically assess the validity of out identification strategy by means of both pretrend falsification tests and placebo simulations.

Along the lines discussed in Section IIB, we test the impact of two leads and two lags of newspaper net entry $\left(\Delta n_{i(t-k)}\right)$, as well as of contemporaneous net entry (for $k=0$ ), on the relevant outcomes. Specifically, we focus on the outcomes for which we detected significant effects with our baseline results, namely, turnout, reelection, and government efficiency (the latter both in the all sample and for mayors facing reelection incentives). Leads and lags are calculated by electoral terms, as our outcome variables only vary by term. We first estimate 5 separate regressions by replacing $\Delta n_{i t}$ with $\Delta n_{i(t-k)}$ in equation (3), so as to have a large enough sample to identify a coefficient $\beta^{k}$ for each $k=-2,-1,0,1,2$.

In Figure 5, we report the estimated coefficients of these regressions and 95 percent confidence intervals. Importantly, for $k=-2,-1$, no point estimate is statistically different from zero, supporting the assumption that treated and control municipalities were not on separate outcome trends before the entry or exit of newspapers. In terms of dynamics, there are no delayed effects of net newspaper entry in

\footnotetext{
${ }^{23}$ To shed more light on the coverage of local news by different types of newspapers, we implemented a case study on one Italian region (Emilia Romagna) based on the database Factiva, containing all articles by a subset of newspapers in our sample. We searched for the number of articles mentioning mayors who ran for reelection or their future challengers over the first term. Articles about challengers are about 10 percent of those about incumbents in local newspapers, as opposed to 30 percent in national newspapers. In general, the number of articles covering local politicians is higher in local than in national newspapers.
} 


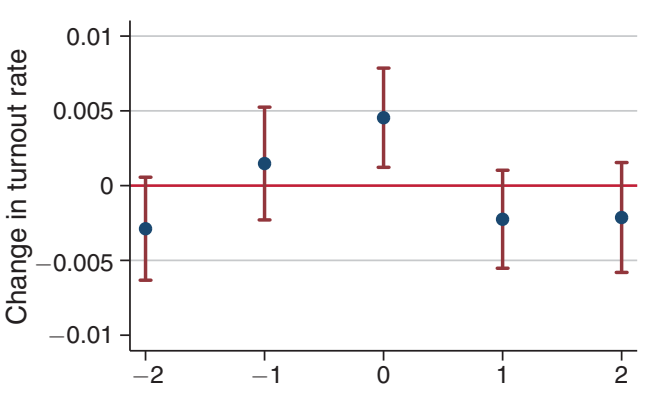

Terms from change in number local editions

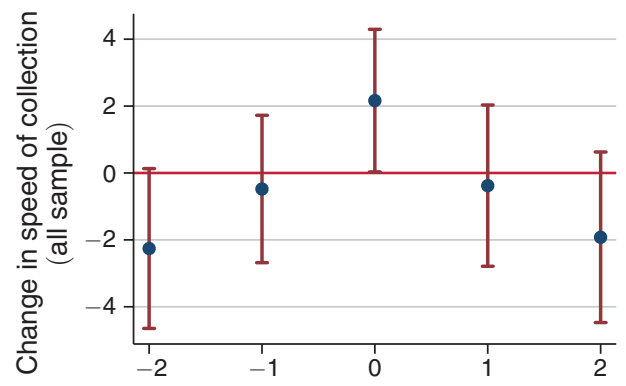

Terms from change in number local editions

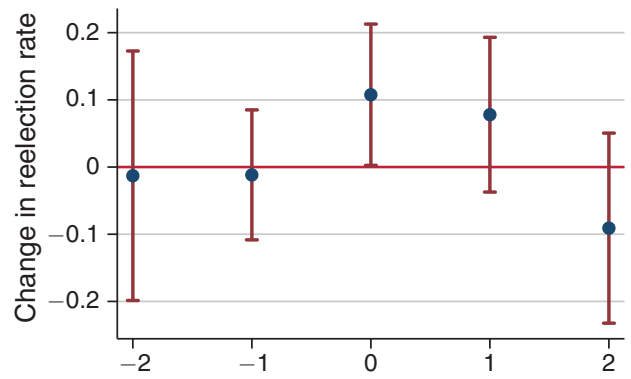

Terms from change in number local editions

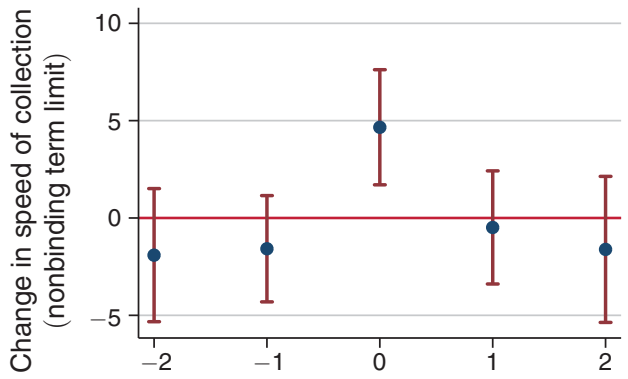

Terms from change in number local editions

Figure 5. Changes in Relevant Outcomes around NewsPaPer Entry and Exit

Notes: Dependent variables: turnout rate, reelection rate (mayors who run for reelection only), speed of collection (all sample), and speed of collection (mayors with nonbinding term limit only). Models are estimated as in equation (3) by replacing $\Delta n_{i t}$ with the leads/lags $\Delta n_{i(t-k)}$, with $k=-2,-1,0,1,2$. In other words, the graphs show regression coefficients of two leads (by term) and two lags (by term) with respect to the electoral term of entry or exit of a (print) newspaper local edition. Standard errors are clustered by city. Bars represent 95 percent confidence intervals.

subsequent terms (for $k=1,2$ ), although this might be due to future adjustments in the local media market. In online Appendix Figure A8, as a further robustness check, we estimate equation (4) in a unique sample. Because of data limitation, we can only estimate this specification with $k=-1,0,1$. It is reassuring, however, that also in this case there is virtually no association between current changes in the number of newspapers and past changes in the relevant outcomes.

In online Appendix Figure A9, we also exploit the annual variability of our data by estimating a version of equation (4) in which $k$ captures the years from the entry/ exit episode. We estimate it with $k=-3,-2,-1,0,1,2,3$ because we want to focus on the term preceding and on the term following net entry. Coefficients on the left of zero test for the existence of any (yearly) pretrend between treated and control cities; coefficients on the right of zero detect heterogeneous effects due to newspaper entry happening one, two, or three years before the year of election. No significant pretrend is evident in any outcome. In terms of dynamics, government efficiency is the outcome with more delayed effects, as the impact is initially larger for years farther away from the entry episode. ${ }^{24}$

\footnotetext{
${ }^{24}$ Online Appendix Tables A4, A5, and A6 directly evaluate whether the net entry of newspapers is determined by past realizations of the relevant outcomes, again finding no evidence of any pretrend. As a final falsification
} 
Finally, as discussed in Section IIB, we perform a series of permutation-based placebo tests (see online Appendix Figures A10-A13). Specifically, the figures show the cumulative distribution function of 10,000 placebo estimates of the impact of false entries and exits on the relevant outcomes. Placebo coefficients are normalized as percentage points of the true baseline result. This means, for instance, that a normalized coefficient of 100 stands for a placebo estimate equal to the baseline estimate. To validate our results, we expect most normalized coefficients to be close to 0 , and to observe only a few of them outside the interval $[-100,+100]$-in fact no more than 5 percent in each tail. Indeed, for turnout, only 0.02 percent of the false effects are above 100, and none of them are below -100 . For reelection, 0.32 percent are above 100 and 0.1 percent below -100 . For government efficiency in the all sample, 0.08 percent are above 100 , and 0.1 percent below -100 . For government efficiency in the sample of mayors who can be reelected, none of the false effects is outside the interval from -100 and 100 . Overall, this evidence strongly reinforces the conclusion that our baseline results cannot just be attributed to random chance.

\section{Conclusion}

This paper evaluates how newspapers affect electoral participation, as well as the selection and the performance of politicians. We use an original dataset covering the presence of local news by different types of newspapers for medium-large Italian municipalities, and find a robust positive impact of the supply of local news on turnout, the reelection probability of incumbent mayors, and municipal government efficiency. Our heterogeneity results show that print editions, local newspapers, and existing newspapers have a larger impact on local politics than their counterparts (that is, online editions, national newspapers, and new newspapers, respectively). Overall, our evidence shows that newspapers still remain a uniquely important source of information on local politics.

The institutional framework of Italian municipalities, where mayors face a two-term limit, provides the perfect testing ground to shed more light on the potential channels linking newspapers and politicians' behavior. Our results show that the effect of newspapers on government efficiency is (considerably) larger when mayors are in their first term, and thus face reelection incentives. At the same time, there is no compelling evidence that newspapers have a relevant impact on the (observable) characteristics of elected mayors. Although we cannot rule out the existence of any effect of newspapers on the unobservable characteristics of mayors, this evidence suggests that incentives-rather than selection-seem to represent the main channel linking newspapers and politicians' behavior.

We also find that competition does matter, as the positive impact of newspaper entry does not vanish when more newspapers are in the market. From a comparative perspective, our results are relevant for the debate on competition and localism in

exercise, we predict the relevant outcomes from our socioeconomic covariates (listed in Table 3), and then regress the predicted values on newspaper net entry; none of the estimates is statistically different from 0 : -0.0001 for turnout ( $p$-value: 0.403$),-0.0048$ for reelection $(0.538), 0.0096$ for revenue collection in the all sample $(0.891)$, $0.0128(0.884)$. 
the United States. We provide supporting evidence to the claim that promoting localism and competition in the market for news may have positive effects on electoral participation and on government performance.

\section{REFERENCES}

Autorità Per Le Garanzie Nelle Comunicazioni (AGCOM). 2009. Relazione Annuale sull'Attività Svolta e sui Programmi di Lavoro. AGCOM, Italy.

Agostini, Angelo, and Mario Lenzi. 2002. "L'Italia dei Comuni, tra Politica e Giornali." Problemi dell'Informazione 27 (4): 431-40.

-Ansolabehere, Stephen, Erik C. Snowberg, and James M. Snyder, Jr. 2006. "Television and the Incumbency Advantage in U.S. Elections.” Legislative Studies Quarterly 31 (4): 469-90.

Associazione Nazionale Comuni Italiani (ANCI). 2012. Il Quadro Finanziario dei Comuni: Rapporto Ifel 2012. Istituto per la Finanza e l'Economia Locale (iFEL). Rome, July.

Besley, Timothy. 2007. Principled Agents?: The Political Economy of Good Government. Oxford, UK: Oxford University Press.

- Besley, Timothy, and Robin Burgess. 2002. "The Political Economy of Government Responsiveness: Theory and Evidence from India." Quarterly Journal of Economics 117 (4): 1415-51.

Besley, Timothy, and Andrea Prat. 2006. "Handcuffs for the Grabbing Hand? Media Capture and Government Accountability." American Economic Review 96 (3): 720-36.

Casaburi, Lorenzo, and Ugo Troiano. 2012. "Ghost-House Busters: The Electoral Response to a Large Anti Tax Evasion Program." Unpublished.

Castronovo, Valerio. 2008. "Il Sistema Editoriale e l'Industria dell'Informazione." In La Stampa Italiana nell'Età della TV, edited by Valerio Castronovo and Nicola Tranfaglia. Bari: Laterza.

DellaVigna, Stefano, and Ethan Kaplan. 2007. “The Fox News Effect: Media Bias and Voting." Quarterly Journal of Economics 122 (3): 1187-1234.

Degan, Arianna, and Antonio Merlo. 2011. "A Structural Model of Turnout and Voting in Multiple Elections." Journal of the European Economic Association 9 (2): 209-45.

-DellaVigna, Stefano, and Matthew Gentzkow. 2010. "Persuasion: Empirical Evidence.” Annual Review of Economics 2 (1): 643-69.

-Di Tella, Rafael, and Ignacio Franceschelli. 2011. "Government Advertising and Media Coverage of Corruption Scandals." American Economic Journal: Applied Economics 3 (4): 119-51.

Downs, Anthony. 1957. An Economic Theory of Democracy. New York: Harper.

Drago, Francesco, Tommaso Nannicini, and Francesco Sobbrio. 2014. "Meet the Press: How Voters and Politicians Respond to Newspaper Entry and Exit: Dataset." American Economic Journal: Applied Economics. http://dx.doi.org/10.1257/app.6.3.159.

Durante, Ruben, and Brian Knight. 2012. "Partisan Control, Media Bias, and Viewer Responses: Evidence from Berlusconi's Italy." Journal of the European Economic Association 10 (3): 451-81.

-Eisensee, Thomas, and David Strömberg. 2007. "News Droughts, News Floods, and U.S. Disaster Relief." Quarterly Journal of Economics 122 (2): 693-728.

Fabbri, Lorenzo. 2004. "Locale, locale, locale." Problemi dell'informazione 24 (1): 74-108.

-Feddersen, Timothy. 2004. "Rational Choice Theory and the Paradox of Not Voting." Journal of Economic Perspectives 18 (1): 99-112.

Feddersen, Timothy J., and Wolfgang Pesendorfer. 1996. "The Swing Voter's Curse." American Economic Review 86 (3): 408-24.

Fergusson, Leopoldo. 2012. "Media Markets, Special Interests, and Voters." Universidad de los Andes Cede Working Paper 2012-08.

-Ferraz, Claudio, and Frederico Finan. 2008. "Exposing Corrupt Politicians: The Effects of Brazil's Publicly Released Audits on Electoral Outcomes.” Quarterly Journal of Economics 123 (2): 703-45.

Gagliarducci, Stefano, and Tommaso Nannicini. 2013. "Do Better Paid Politicians Perform Better? Disentangling Incentives from Selection." Journal of the European Economic Association 11 (2): 369-98.

-Galasso, Vincenzo, and Tommaso Nannicini. 2011. "Competing on Good Politicians." American Political Science Review 105 (1): 79-99.

-Gentzkow, Matthew. 2006. "Television and voter turnout." Quarterly Journal of Economics 121 (3): 931-72.

Gentzkow, Matthew, Nathan Petek, Jesse M. Shapiro, and Michael Sinkinson. 2012. "Do Newspapers Serve the State? Incumbent Party Influence on the US Press, 1869-1928." National Bureau of Economic Research (NBER) Working Paper 18164. 
Gentzkow, Matthew, Jesse M. Shapiro, and Michael Sinkinson. 2011. "The Effect of Newspaper Entry and Exit on Electoral Politics.” American Economic Review 101 (7): 2980-3018.

George, Lisa M., and Joel Waldfogel. 2008. "National Media and Local Political Participation: The Case of the New York Times." In Information and Public Choice: From Media Markets to Policymaking, edited by Roumeen Islam, 33-48. Washington, DC: World Bank Publications.

Gerber, Alan, S., and Donald P. Green. 2000. "The Effects of Canvassing, Telephone Calls, and Direct Mail on Voter Turnout: A Field Experiment.” American Political Science Review 94 (3): 653-63.

Grandinetti, Mario. 2008. "La Proprietà dei Quotidiani e delle Televisioni Nazionali." In La Stampa Italiana nell'Età della TV, edited by Valerio Castronovo and Nicola Tranfaglia, 667-719. Bari: Laterza.

Green, Donald P., and Alan S. Gerber. 2008. Get Out the Vote: How to Increase Voter Turnout. Washington, DC: Brookings Institution Press.

Holmström, Bengt. 1999. "Managerial Incentive Problems: A Dynamic Perspective." Review of Economic Studies 66 (1): 169-92.

Iannace, Arcangelo. 1989. Un Giornale, Una Provincia. Torino: Gutenberg.

Inter-Parliamentary Union. 2011. Women in National Parliaments: World Classification. Inter-Parliamentary Union (IPU). http://www.ipu.org/wmn-e/classif.htm.

Isnenghi, Mario. 2008. "La Stampa Quotidiana Locale.” In La Stampa Italiana nell'Età della TV, edited by Valerio Castronovo and Nicola Tranfaglia, 313-44. Bari: Laterza.

- Larcinese, Valentino. 2009. "Information Acquisition, Ideology and Turnout: Theory and Evidence from Britain." Journal of Theoretical Politics 21 (2): 237-76.

Lassen, David D. 2005. "The Effect of Information on Voter Turnout: Evidence from a Natural Experiment." American Journal of Political Science 49 (1): 103-18.

Lenzi, Caterina. 2001. Giornali e Giornalisti. Roma: Editori Riuniti.

- Matsusaka, John G. 1995. "Explaining voter turnout patterns: An information theory." Public Choice 84 (1-2): 91-117.

Merlo, Antonio M., Vincenzo Galasso, Massimiliano Landi, and Andrea Mattozzi. 2010. "The Labor Market of Italian Politicians." In The Ruling Class: Management and Politics in Modern Italy, edited by Tito Boeri, Antonio Merlo, and Adrea Prat, 9-106. Oxford, UK: Oxford University Press.

Miner, Luke. 2012. "The Unintended Consequences of Internet Diffusion: Evidence from Malaysia." Unpublished.

Murialdi, Paolo, and Nicola Tranfaglia. 2008. "I Quotidiani negli Ultimi Venticinque Anni. Crisi, Sviluppo e Concentrazioni." In La Stampa Italiana nell'Età della TV, edited by Valerio Castronovo and Nicola Tranfaglia, 3-62. Bari: Laterza.

-Oberholzer-Gee, Felix, and Joel Waldfogel. 2009. "Media Markets and Localism: Does Local News en Español Boost Hispanic Voter Turnout?" American Economic Review 99 (5): 2120-28.

Organisation for Economic Co-operation and Development (OECD). 2010. The Evolution of News and the Internet. OECD Publishing. Paris, June.

Popkin, Samuel L. 1991. The Reasoning Voter: Communication and Persuasion in Presidential Campaigns. Chicago: University of Chicago Press.

Prat, Andrea, and David Strömberg. 2005. "Commercial Television and Voter Information.” Centre for Economic Policy Research (CEPR) Discussion Paper 4989.

Prat, Andrea, and David Strömberg. 2011. "The Political Economy of Mass Media.” http://people. su.se/ dstro/mediasurvey10-10-04.pdf.

-Prior, Markus. 2006. "The Incumbent in the Living Room: The Rise of Television and the Incumbency Advantage in U.S. House Elections." Journal of Politics 68 (3): 657-73.

Prior, Markus. 2007. Post-Broadcast Democracy. New York: Cambridge University Press.

-Snyder, James M., Jr., and David Strömberg. 2010. "Press Coverage and Political Accountability." Journal of Political Economy 118 (2): 355-408.

-Strömberg, David. 2004. "Radio's Impact on Public Spending." Quarterly Journal of Economics 119 (1): 189-221. 